\title{
Spent Bleaching Earth Recovery of Used Motor-Oil Refinery
}

\author{
Mohammad Reza Sabour ${ }^{\mathrm{a}}$, Mahsa Shahi ${ }^{\mathrm{b}}$ \\ ${ }^{a}$ Associate professor, K. N. Toosi University of Technology, Tehran, Iran. \\ ${ }^{b *}$ PhD. student, Amirkabir Unuiversity of Technology, Tehran, Iran.
}

Received 27 October 2017; Accepted 11 March 2018

\begin{abstract}
Bleaching earth refers to natural or activated clay which has the capacity to adsorb colored materials and other impurities during oil purification processes. This research utilized the spent bleaching earth (SBE) in used motor oil purification process via thermal remediation $\left(650{ }^{\circ} \mathrm{C}\right)$ and acid washing methods $(1 \mathrm{M} \mathrm{HCl})$. Then, the activated spent bleaching earth (ASBE) was characterized. The results obtained from the BET analysis show the specific surface area and pore volume of the ASBE, activated virgin bleaching earth (AVBE) and virgin bleaching earth (VBE). These parameters are $100.38 \mathrm{~m}^{2} \mathrm{~g}-$ ${ }^{1}$ and $0.23 \mathrm{~cm}^{3} \mathrm{~g}^{-1}$ for the activated spent bleaching earth, $100.82 \mathrm{~m}^{2} \mathrm{~g}^{-1}$ and $0.22 \mathrm{~cm}^{3} \mathrm{~g}^{-1}$ for the activated virgin bleaching earth and $83.34 \mathrm{~m}^{2} \mathrm{~g}^{-1}$ and $0.19 \mathrm{~cm}^{3} \mathrm{~g}^{-1}$ for the virgin bleaching earth. The BJH analysis indicates that SBE activation increases mesopores in ASBE. In addition, results obtained from the XRD and FTIR tests illustrate that activation of SBE does not affect the physical and chemical properties of montmorillonite clay. Furthermore, SEM observations indicate surface morphology improvement in ASBE. Hence, activation of earth enhances its adsorption efficiency in comparison with virgin bleaching earth.
\end{abstract}

Keywords: Spent Bleaching Earth; Activated Earth; Remediation; Activation; Analysis Methods.

\section{Introduction}

One of the purification steps is the bleaching stage. Natural absorbent such as completely activated soil, and activated carbon are the main absorbent and are collectively called bleaching earth. Bleaching earth is used to improve the quality and stabilize the color of final product in used motor oil regeneration. Bleaching earth consists of clays which have capacity of adsorbing color and other undesirable elements of used oil during its purification processes in their natural or activated status [1]. These clays are usually bentonite from montmorillonite group with compact masses of crystalline aluminum silicates, containing various amounts of alkaline and intermediate metals [2]. Bleaching process is usually carried out by bentonite clay called as virgin bleaching earth (VBE) [3]. Elimination of undesirable elements includes oil color and heavy metals from used vegetable oil [4]. Thus, spent bleaching earth (SBE) remains, when impurities adsorb into VBE.

SBE as pollutant contains $20-40 \%$ by weight oil [5] and it is flammable and may cause fire. Disposal of SBE without pre-treatment in a landfill leads to loss of a large amount of oil as well as financial loss, while it causes hazards to the environment [6]. Based on latest researches, about 300-350 thousand tons of used motor oil is produced annually in Iran, where the cleaning method is acid washing and bleaching utilizing clay [7]. According to studies by USA Department of Energy, about 9 million $\mathrm{m}^{3}$ of lubricants (in forms of motor oil, industrial oil, hydraulic oil, and grease) are consumed annually [8]. However, 40\% remained materials after consumption enter waste management stream. In addition, 4.9 million tons of lubricating oil is used in Europe, and 36\% remained materials after utilization are recycled [9]. SBE can be produced from clearing unit (the fifth stage of purification of used motor oil). According to an initial estimation and oil absorption, the size of filtered clay particles increases after bleaching process and pollutants absorption [10]. In fact,

* Corresponding author: mshahi@aut.ac.ir

$>$ This is an open access article under the CC-BY license (https://creativecommons.org/licenses/by/4.0/).

(C) Authors retain all copyrights. 
about 80 to $140 \mathrm{~kg}$ of filtered clay per ton of refined used oil is generated in this process.

Taking into account the initial economic analysis, the overall investment and operation costs can be divided into two components, as follows. First, the initial investment includes design and implementation components. Second, the recycling unit consists of clay exploitation (maintenance) area. The revenue required transport and recycled clay costs, which are less in Iran in comparison with the global market. The average price of bentonite was approximately $\$ 60$ per ton worldwide in 2015 . However, in Iran the price of bentonite was about $\$ 35$ to 40 per ton in 2015. Moreover, proper investment and principles will lead to profit-making [1].

In accordance with the regulations of waste management, manufacturers are obliged to reduce the amount of special waste and pollution (20\% by weight of oil production) [11]. European law on management of used motor oil in 1975 (75/439/EC) emphasized on ecological management practices and establishment of oil refineries compared to incineration and energy recovery facilities [9]. However, recycling and incineration have been proposed as alternatives in Canadian executive law [12]. These regulations encourage factories to apply any recycling methods even new processes instead of the acid-clay method to mitigate environmental impacts and take into account economic issues of concern [13].

Regeneration of this waste has aroused a great interest among many researchers. This is generally done thermally, or via chemical purification, solvent extraction, or a combination of these methods. Some of the studies in this regard are as follows (Table 1):

Table 1. Important studies on motor-oil recovery

\begin{tabular}{|c|c|c|c|c|c|}
\hline No. & Researcher (s) & Year & Research title & Conclusion & Reference \\
\hline 1 & Yildiz et al. & 2004 & $\begin{array}{l}\text { Sulphuric acid activation of a calcium } \\
\text { bentonite }\end{array}$ & $\begin{array}{c}\text { The maximum specific surface area }(240.9 \\
\left.\mathrm{m}^{2} \mathrm{~g}^{-1}\right) \text { was obtained via sample activation } \\
\text { with } 2 \mathrm{M} \mathrm{H} 2 \mathrm{SO} 4\end{array}$ & [14] \\
\hline 2 & $\begin{array}{l}\text { Meesuk and } \\
\text { Vorasith }\end{array}$ & 2006 & $\begin{array}{l}\text { The use of bentonite to remove dark } \\
\text { colour in repeatingly used palm oil }\end{array}$ & $\begin{array}{c}\text { Chemical and physical properties of } \\
\text { bentonite were analyzed by XRD and SEM } \\
\text { tests }\end{array}$ & [15] \\
\hline 3 & Noyan et al. & 2007 & $\begin{array}{l}\text { The effect of sulphuric acid activation } \\
\text { on the crystallinity, surface area, } \\
\text { porosity, surface acidity, and bleaching } \\
\text { power of a bentonite }\end{array}$ & $\begin{array}{c}\text { The content of } \mathrm{H}_{2} \mathrm{SO}_{4} \text { in acidic bentonite } \\
\text { changed from } 0 \text { to } 70 \%\end{array}$ & [16] \\
\hline 4 & Sarioglan et al. & 2010 & $\begin{array}{l}\text { Acid Activation and Bleaching } \\
\text { Performance of Turkish (Somas) } \\
\text { Bentonite in Crude Soybean Oil }\end{array}$ & $\begin{array}{l}\text { The structures of bentonite was examined } \\
\text { using FTIR, TGA and DTA tests following } \\
\text { activation }\end{array}$ & [17] \\
\hline 5 & Mana et al. & 2011 & $\begin{array}{l}\text { Regeneration of spent bleaching earth } \\
\text { by treatment with } \\
\text { cethyltrimethylammonium bromide for } \\
\text { application in elimination of acid dye }\end{array}$ & $\begin{array}{l}\text { Surface area, pore volume and pore } \\
\text { distribution increased by } 40 \%\end{array}$ & [18] \\
\hline 6 & Emam and Shoaib & 2013 & $\begin{array}{l}\text { Re-refining of used lube oil, I- by } \\
\text { solvent extraction and vacuum } \\
\text { distillation followed by hydrotreating }\end{array}$ & $\begin{array}{l}\text { The re-refining using vacuum distillation } \\
\text { gave the highest oil yield of about } 84 \% \\
\text { compared to solvent extraction (about } 78 \% \text { ). }\end{array}$ & [19] \\
\hline 7 & Abu-Elella et al. & 2015 & $\begin{array}{l}\text { Used Motor Oil Treatment: Turning } \\
\text { Waste Oil Into Valuable Products }\end{array}$ & $\begin{array}{l}\text { Formic acid-clay treatment improve the } \\
\text { flash point of the used motor oil }\end{array}$ & [20] \\
\hline 8 & Loh et al. & 2017 & $\begin{array}{c}\text { Surface-active physicochemical } \\
\text { characteristics of spent bleaching earth } \\
\text { on soil-plant interaction and water- } \\
\text { nutrient uptake: A review }\end{array}$ & $\begin{array}{l}\text { SBE's structural characteristics, surface } \\
\text { chemistry and activation have been } \\
\text { disclosed }\end{array}$ & {$[21]$} \\
\hline
\end{tabular}

Referring to the results obtained in Table 1, in this research SBE activation followed by thermal treatment (removal of contaminated motor oil from bleaching earth) in furnace and acid washing (activating and improving clay properties) through $\mathrm{HCl}$ solution on SBE. Oil color measurement with colorimeter is employed to select the optimum sample. Then, physico-chemical characteristics (BET and BJH analysis, XRD, FTIR and SEM) of activated spent bleaching earth (ASBE) is compared with VBE and activated virgin bleaching earth (AVBE) samples in similar conditions. This study aims to evaluate the clay structure along with activation method.

\section{Materials and Methods}

In this section utilized materials and equipment, and performed experiments are described. It is to be mentioned that all laboratory containers and equipment were washed with detergents and distilled water and were dried prior to performing the experiments. After determining oil content of SBE, soil activation (through thermal remediation and acid washing) is followed homogenized SBE particles. Experiments were conducted on size of 2-3 mm. 


\subsection{Utilized Materials}

Materials used in this research included used motor oil, VBE (moisture content, $\omega=2.6 \%$ ), SBE contained motor oil, and $\mathrm{HCl}(37 \%)$. Also used motor oil and used clay was obtained from a purification unit of used oil recycling plant. The bleaching earth used in this plant was raw calcium bentonite consist of $85 \%$ Montmorillonite (size less than 0.002 $\mathrm{mm}$ ) produced in Iran. In addition, bentonite clay (in this research) was composed of $0.96 \% \mathrm{CaO}, 69.8 \% \mathrm{SiO}_{2}$ and $11.88 \% \mathrm{Al}_{2} \mathrm{O}_{3}$. Thermal remediation of $\mathrm{SBE}$ was carried out in a Gallen Kamp furnace. Acid improvement was performed using $\mathrm{HCl}(37 \%)$ produced by Merck company. The main materials and apparatus are illustrated in Figure 1.

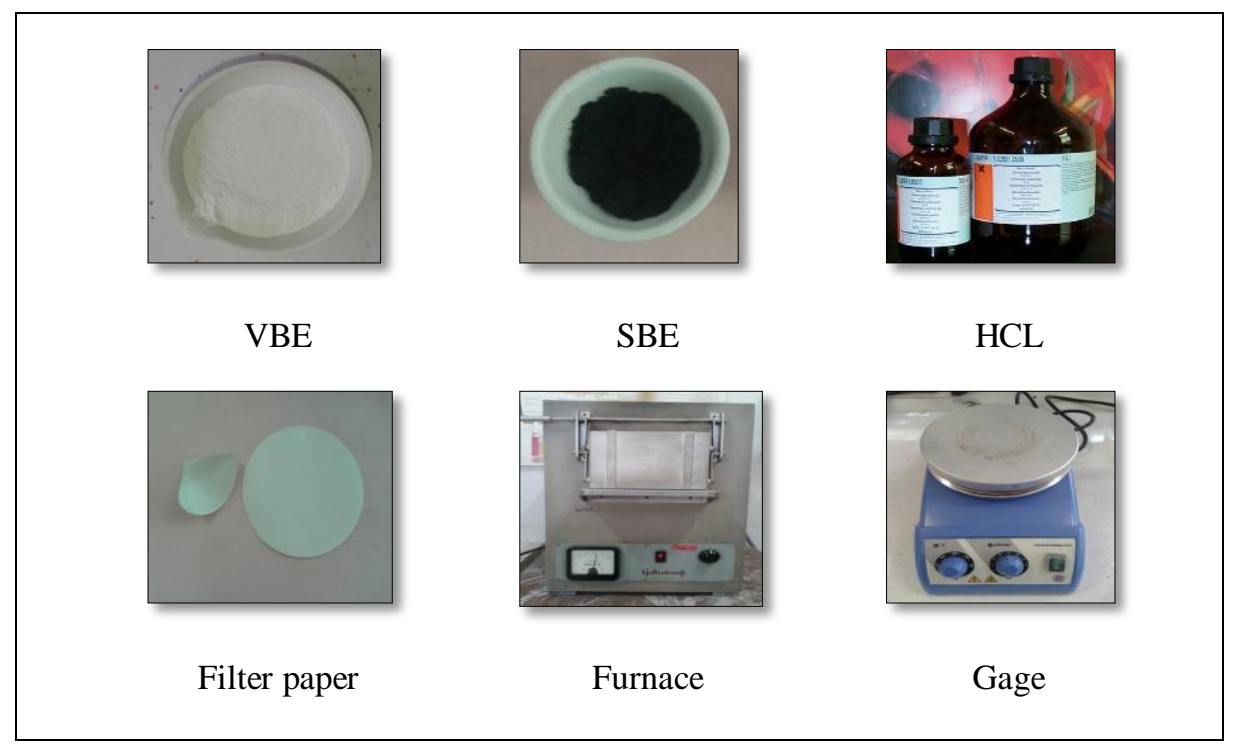

Figure 1. Main material and measuring apparatus

\subsection{Experiments}

At first, Soxhlet and furnace experiments were carried out to determine the oil content of SBE. Then, thermal remediation of SBE was carried out in furnace at various temperatures to obtain clay without contaminants. Afterwards, acid washing of the remediated sample was performed by using $\mathrm{HCl}(37 \%)$ to activate the clay.

\subsubsection{Oil Measurement of Contaminated Clay}

Soxhlet and furnace experiments were carried out as described below. The actual oil content of contaminated clay was calculated by comparing the results of these two methods, as follows:

Soxhlet experiment: Keeping SBE in a plastic bag at room temperature $\left( \pm 25^{\circ} \mathrm{C}\right), 10 \mathrm{~g}$ of SBE was placed in a Soxhlet extractor. Methyl Ethyl Ketone (MEK) with high solubility was a suitable solvent for performing a faster and more accurate Soxhlet experiment. Two hundred milliliter of MEK was poured into a round-bottom flask at the lower end of the Soxhlet extractor. The experiment was conducted under a vacuum hood due to flammability of MEK. The solvent was siphoned to the heating flask after 30 minutes and siphon cycle was repeated at 10 minute intervals. After 10 hours, the system was stopped and the heater and cooler were removed [22].

The flask at lower end of the extractor containing the mixture of oil and solvent was removed and transferred to a place for separating the oil from the solvent. Using Soxhlet experiment, almost the entire oil within SBE was removed. The mixture of oil and solvent was poured into a special flask and mounted in a rotary evaporator. After 10 minutes running the evaporator, the solvent was evaporated under vacuum and collected in the side container, while the oil in the solvent remained in the original flask. To improve the accuracy of experiment, the extractor was kept on for another 10 minutes to obtain oil to highest possible amount. Then, evaporator was turned off and the flask containing the oil was placed in a desiccator to cool it down without adsorbing moisture after an hour, the flask was weighed to obtain the weight of extracted oil.

Furnace experiment: In order to confirm results from Soxhlet experiment, furnace experiment was conducted. Flash point of motor oil is $226{ }^{\circ} \mathrm{C}$. Hence, a $10 \mathrm{~g} \mathrm{SBE}$ sample was placed in a furnace at $200-800{ }^{\circ} \mathrm{C}$ for 1 hour to make sure of complete oil burning [23]. The best reduction chose after repetitive experiments for 3 times in each temperature. The sample weight reduction determined natural moisture of VBE and quantity of oil removal and impurities from the clay. Therefore, the amount of oil removal from SBE in this experiment equals to the summation of oil content and a lot of its impurities (solid particles). 


\subsubsection{Contaminated Clay Remediation and Activation}

The clay was remediated thermally (removing oil from SBE) and it was activated (improvement of its characteristics) through acid washing as described below.

\subsubsection{Thermal Remediation}

Oil content did not change considerably within temperature ranges of $200-400{ }^{\circ} \mathrm{C}$ in furnace experiment. Thus, a limited range with the small interval of $50{ }^{\circ} \mathrm{C}$ was used to depict the oil content changes accurately. On this basis, this test was conducted at temperatures higher than $400{ }^{\circ} \mathrm{C}$.

Having temperature ranges as 400 to $800{ }^{\circ} \mathrm{C}, 50$ gram of SBE was measured by means of an electronic balance with a precision of 0.001 (model FH-303B made by AND Company). Then the clay was placed into the furnace and heated up to the desired temperature for 1 hour [23]. The heated clay located in a desiccator using small crucibles to prevent penetration of moisture into the sample. Cooling down the temperature of the sample to laboratory temperature $\left(24{ }^{\circ} \mathrm{C}\right)$, weight and percentage of oil removed from the sample were measured. This sample was named remediated spent bleaching earth (RSBE).

In this stage, optimum temperature (for removing the entire oil content of the clay) was obtained by performing the experiments. Finding heating duration, the time interval of 0.5-3 hours was selected, and the experiments carried out at the optimum temperature. Using 50g samples in these experiments, the oil content was calculated more accurately compared to $10 \mathrm{~g}$ samples (the furnace experiment). In order to calculate oil removal percentage, Equation 1 was used:

$$
\text { Oil removal }(\%)=\frac{W_{\mathrm{SBE}}-\mathrm{W}_{\mathrm{RSBE}}}{\mathrm{W}_{\mathrm{SBE}}} \times 100-\omega \%
$$

Where, $\mathrm{W}_{\mathrm{SBE}}, \mathrm{W}_{\mathrm{RSBE}}$ and $\omega$ are weight of SBE and RSBE and moisture content of VBE , respectively.

\subsubsection{Acid Washing Activation}

In this test $\mathrm{HCl}$ (37\%) was used to provide solutions with concentration of 0.1-3 M, while the ratio of RSBE to acidic solution was kept 1-20 wt. \% [23]. Acidic solution and RSBE were mixed with a magnetic mixer (model PLOE IDEAL PARS HMS8805) at $25 \pm 2{ }^{\circ} \mathrm{C}$ for one hour at a speed of $300 \mathrm{rpm}$ [24]. After complex mixing by magnetic mixer, acidic phase and leached RSBE were separated via centrifuge (model Segurita BHG 1100).

Acid washing was continued until reaching neutral $\mathrm{pH}$ (through injecting $\mathrm{AgNO}_{3}$ for this assurance). Washing the sample 7 times with distilled water, the clay and acid solution passed through a filter paper No. 2 (Ø $12.5 \mathrm{~mm})$. The remaining clay on the filter paper was put inside an oven for 24 hours at $80{ }^{\circ} \mathrm{C}$. The obtained sample was grinded with porcelain mortar in order to become powder and increase the clay absorbability. Powdered sample was named as ASBE. Furthermore, the same process (thermal remediation and acid washing) was applied on VBE sample in order to compare AVBE with ASBE sample in terms of oil removal efficiency.

\subsubsection{Oil Color Measurement}

Completing clay activation, a colorimeter (Tintometer Model F) was used for conducting the oil color measurement test on ASBE in order to prepare the optimum sample [25].Carrying out bleaching operations, $100 \mathrm{~g}$ of contaminated oil were poured in a beaker and mixed under a laboratory hood using a magnetic mixer. The oil was heated to $80{ }^{\circ} \mathrm{C}$, and then $1 \mathrm{~g}$ of ASBE was added to the oil, while heating operation was continuing. Achieving the mixture temperature $110{ }^{\circ} \mathrm{C}$, it was stirred for 5 minutes and then filtered. Color of the filtered oil was determined using a colorimeter in terms of Lovibond units. Passing the contaminated oil (with Lovibond 8) through ASBE, Equation 2 was used to determine the approximate efficiency of bleaching operation:

$$
\eta=\frac{l_{0}-1}{l_{0}} \times 100
$$

Where, $\eta, l_{0}$ and 1 are oil color efficiency, color of contaminated oil, and color of refined oil, respectively.

\subsubsection{Bleaching Earth Characteristics}

Preparing the optimum sample in section 2.2.2, some tests were performed on ASBE, AVBE, and VBE to determine physico-chemical properties in similar laboratory conditions. The porous texture of VBE, AVBE and ASBE was characterized via nitrogen gas Adsorption/Desorption at $77{ }^{\circ} \mathrm{K}$ through measuring the amount of $\mathrm{N}_{2}$ gas that adsorbs onto the adsorbent by means of a volumetric gas adsorption instrument (a product of BEL JAPAN, INC). Prior to isotherm analysis, the sample was degassed at $120^{\circ} \mathrm{C}$ for $12 \mathrm{~h}$ to remove moisture and other volatile materials from sample.

In order to explain the physical adsorption of gas molecules on a solid surface, BET (Brunauer- Emmett- Teller) theory were used in a range of 0.0 and 0.5 relative pressure based on adsorption of $\mathrm{N}_{2}$ at $77^{\circ} \mathrm{K}$. The results allowed calculating various parameters of the recovered clay texture [26]. Also, BJH (Barret- Joyner- Halenda) scheme was 
investigated to calculate pores distribution based on nitrogen adsorption at $77{ }^{\circ} \mathrm{K}$ [27]. Besides, in order to provide detailed information on the crystallographic structure and physical properties of the samples, XRD (X-Ray Diffraction) patterns were conducted via monochromatic $\mathrm{CuK} \alpha$ radiation using PW1800 diffractometer [28]. Moreover, FTIR (Fourier Transform Infrared Spectroscopy) spectra of different samples (lozenge of KBr 1\%) were carried out by means of ABB Bomem FTLA in a range of 4000-400 $\mathrm{cm}^{-1}$ [29]. Furthermore, SEM (Scanning Electron Microscope) observations were run to provide high resolution images of samples (utilizing XL30 Philips scanning electron microscope) [30].

\section{Results and Discussion}

In this section, results from remediation and activation experiments are studied to determine the effective parameters. After determining the oil content of SBE, the optimum values of furnace temperature, heating duration in the furnace, molar concentration of $\mathrm{HCl}$ solution, and the ratio of RSBE to acid solution are determined.

\subsection{Oil Content Determination}

Comparing results of Soxhlet with furnace experiment, actual oil content of SBE is calculated as described below.

\subsubsection{Soxhlet Test}

The oil separated from the solvent was poured in a flask that had been weighed in advance. The flask was weighed and the oil weight of $10 \mathrm{~g}$ sample was found to be $3.57 \mathrm{~g}(35.7 \mathrm{wt}$. \% of the SBE). In addition it is necessary to measure the percentage of oil removal (for comparison) in section 3.1.2.

\subsubsection{Furnace Experiment}

In order to access an optimum temperature for maximum oil removal, furnace experiment is applied to temperature range from $100{ }^{\circ} \mathrm{C}$ to $1000{ }^{\circ} \mathrm{C}$ (Figure 2).

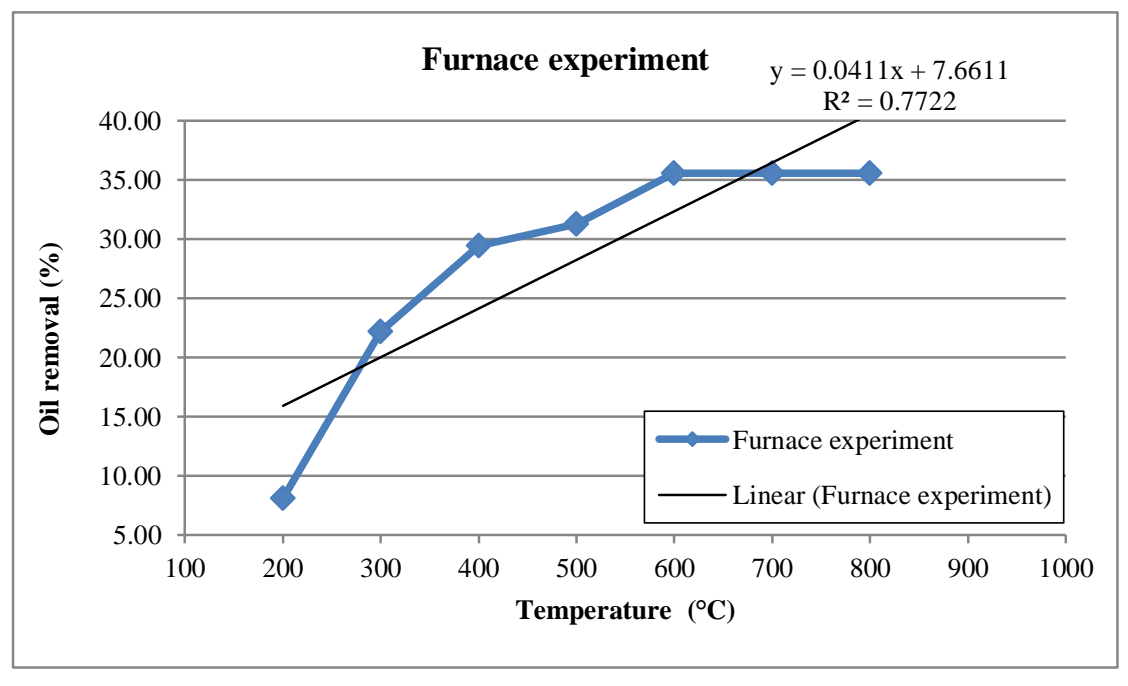

Figure 2. Oil removal variation from SBE by means of furnace experiment

As shown in Figure 2, there is an upward trend of SBE oil removal from 200 to $600{ }^{\circ} \mathrm{C}$, then stabilized beyond the highest temperature. Based on VBE moisture content $(\omega=2.6 \%)$, the maximum oil removal from a $10 \mathrm{~g}$ SBE is 35.5 wt. $\%$ at $600{ }^{\circ} \mathrm{C}$ due to burned part of motor oil and other impurities separation. Soxhlet test implemented more accurate and advanced equipment than furnace. This method measures quantity of oil extracted from SBE through evaporation process (not burning any impurities as in furnace experiment) as $35.7 \mathrm{wt} . \%$.

\subsection{Thermal Remediation}

Temperature and heating duration are two effective parameters in thermal remediation. These parameters are examined as follow.

\subsubsection{Temperature Effect}

In Figure 3, thermal remediation test is conducted for a limited range of temperature to find the maximum oil removal as mentioned in section 3.1.2. 


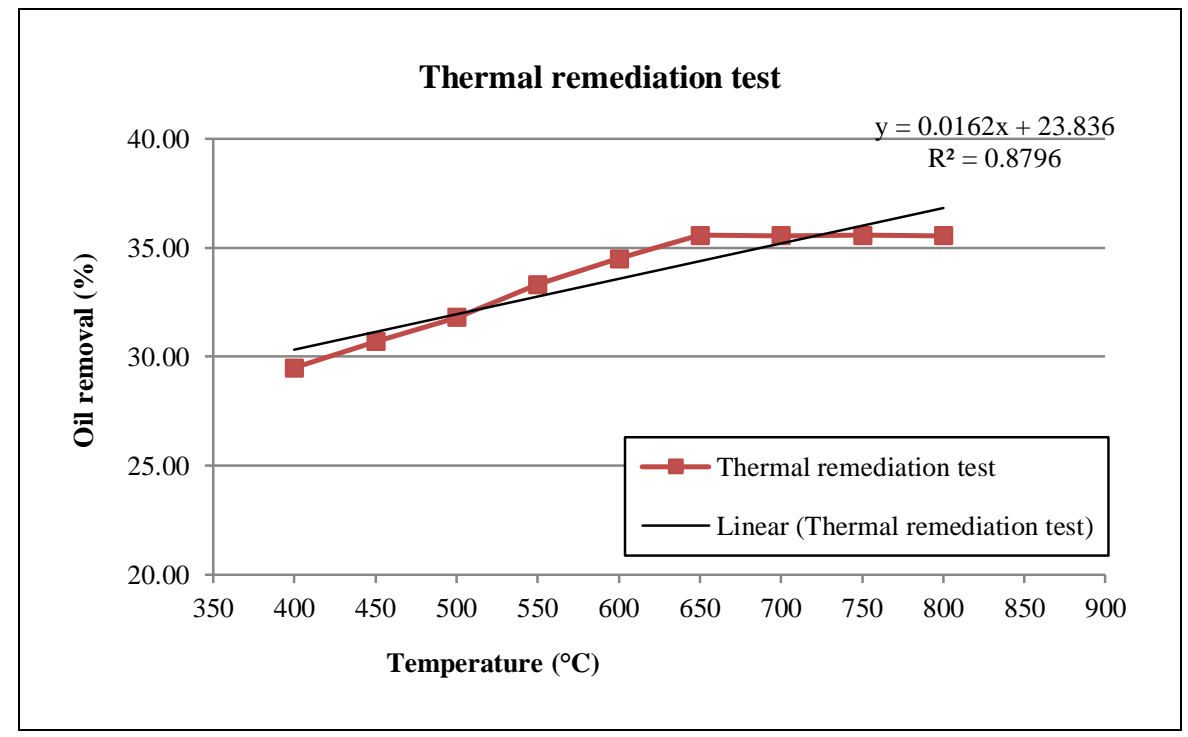

Figure 3. Effect of temperature on oil removal from SBE in thermal remediation test

As shown in Figure 3, in range between $600{ }^{\circ} \mathrm{C}$ and $700{ }^{\circ} \mathrm{C}$, the percentage of oil removal fluctuates around $35 \%$ by weight. It increases with the enhancement of heating temperature of SBE and stabilizes at $650{ }^{\circ} \mathrm{C}$. The result $(35.6 \%$ by weight) is obtained as thermal remediation efficiency.

\subsubsection{Heating Time}

In furnace experiment, duration of heating is highly important due to achieving better oil removal. In Figure 4, various ranges of time are tested to find the best heating time.

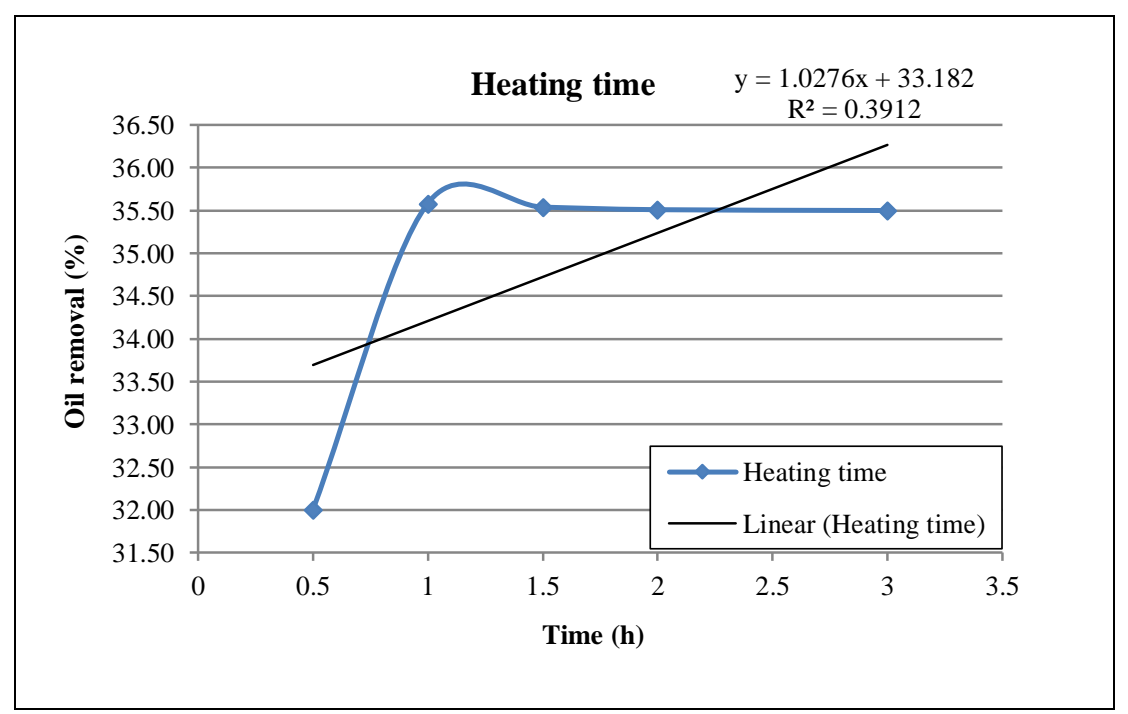

Figure 4. Effect of heating time on oil removal from SBE

The SBE is heated at $650{ }^{\circ} \mathrm{C}$ for $0.5,1,1.5,2,2.5$ and 3 hours. The related results of oil removal are presented in Figure 4 . The heating duration of $1 \mathrm{~h}$ is the best and its oil removal is $35.6 \%$ by weight. The percentage of oil removal is constant at higher heating values. The heated at $650{ }^{\circ} \mathrm{C}$ SBE for $1 \mathrm{~h}$ has more feasible efficiency for elimination of used motor oil.

\subsection{Acid Washing}

Parameters affecting acid washing stage include molar concentration of acid solution and ratio of RSBE to acid solution, which are examined as follows.

\subsubsection{Acid Solution Concentration and RSBE/ Acid Solution Ratio}

In Figure 5, the percentage of color removal versus the ratio of RSBE to acid solution \% by weight is illustrated. For better comparison, acid solution with various concentrations is prepared. 


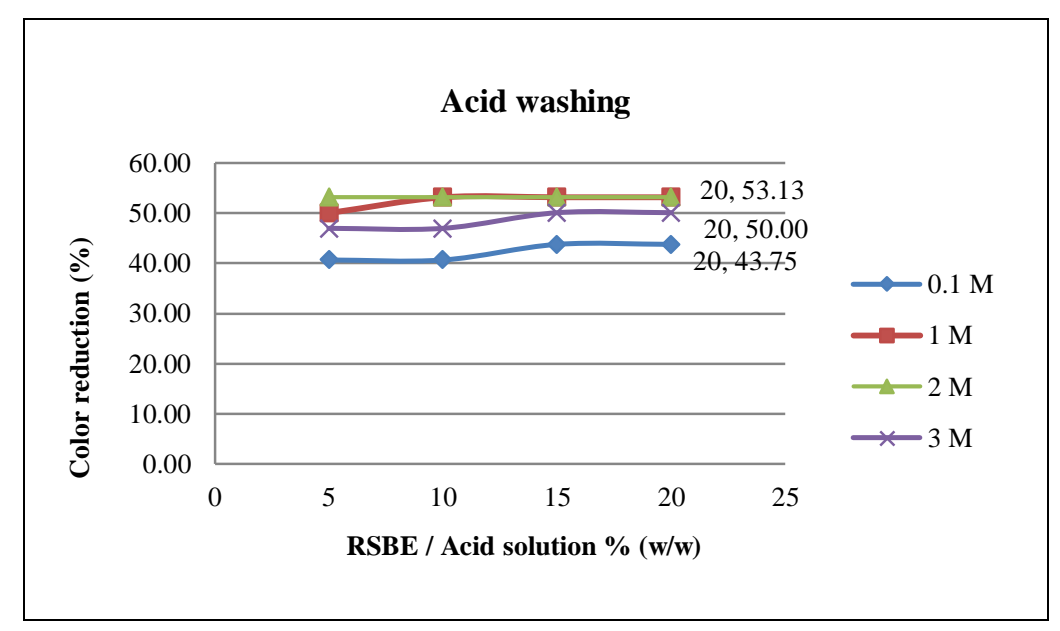

Figure 5. Effect of acid washing on oil color reduction

As shown in Figure 5, the efficiency of RSBE to acid solution concentration ratio is obtained by leaching with 0.1, 1,2 and $3 \mathrm{M} \mathrm{HCl}$ solutions. The process efficiency increases and then stabilizes after the ratio of $15 \%$ by weight. Acid washing illustrates that the optimal acid solution concentration is $1 \mathrm{M}$ with the ratio of $20 \%$ by weight RSBE to acid solution, while it provides $53.1 \%$ efficiency. The molar concentration affects the amount of $\mathrm{H}^{+}$cation substitution for RSBE and improves the properties of the heated sample (RSBE) [31].

\subsection{Optimum Sample Determination}

Considering the results, the optimum sample is the one with heating temperature of $650{ }^{\circ} \mathrm{C}$, heating duration of 1 hour, $\mathrm{HCl}$ solution concentration of $1 \mathrm{M}$, and the ratio of RSBE to acid solution as $20 \%$ by weight.

\subsection{Investigation on Optimized Sample Characteristics}

This section illustrate results of Adsorption/Desorption Isotherm, BET, BJH, XRD, FTIR, and SEM experiments conducted on VBE, AVBE, and ASBE in the following order.

\subsubsection{Adsorption / Desorption Isotherm}

In this part result of Adsorption/ Desorption Isotherm is observed. Experiments are conducted on various samples including VBE, AVBE, and ASBE. In Figure 6, adsorption and desorption are considered, separately.

Table 2. Results summary of Adsorption / Desorption Isotherm

\begin{tabular}{ccc}
\hline Sample & Sample weight $(\mathbf{g r})$ & Saturated vapor pressure $\mathbf{( k P a )}$ \\
\hline VBE & 0.1520 & 91.009 \\
AVBE & 0.2101 & 88.515 \\
ASBE & 0.1127 & 88.541 \\
\hline
\end{tabular}

Table 2 presents characteristics of the samples. As mentioned in this table, AVBE with $0.2101 \mathrm{~g}$ has lower vapor pressure (8.515 KPa) than VBE and AVBE.

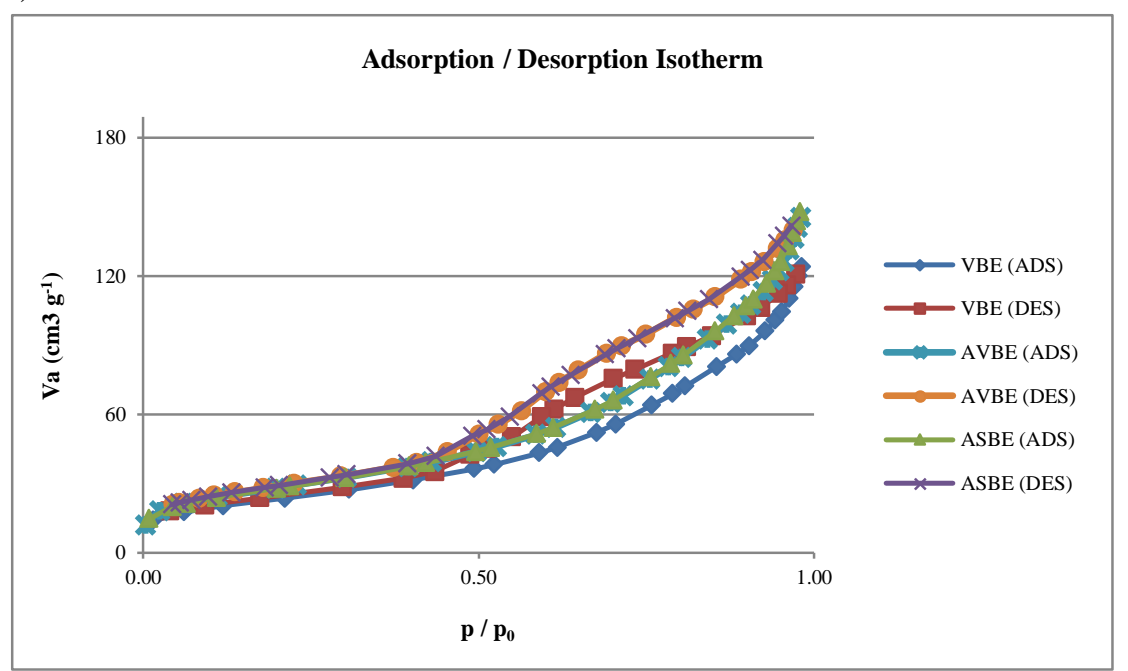

Figure 6. Adsorption/Desorption Isotherms of nitrogen at $77^{\circ} \mathrm{K}$ on VBE, AVBE, and ASBE samples 
As shown in Figure 6, nitrogen adsorption isotherms for VBE, AVBE, and ASBE samples are very similar. These isotherms are type IV in BDDT (Brunauer, Deming, Deming, and Teller) and type H3 hysteresis in IUPAC (International Union of Pure and Applied Chemistry) classification systems, respectively. The type IV isotherm shows mesopores materials with slit-shaped pores, which appears mostly in layered structure clays. The type H3 hysteresis isotherm shows accumulation of layered particles with heterogeneous sizes. These classifications show clearly a vast surface area for the particles and high porosity for the sample mass, respectively [32].

\subsubsection{BET Analysis}

The parameters and results of BET transformation are presented in Table 3 and Figure 7 as follow. BET analysis is conducted on VBE, AVBE, and ASBE.

Table 3. Results summary of BET analysis

\begin{tabular}{|c|c|c|c|c|c|c|c|}
\hline Sample & $\begin{array}{c}\text { Sample } \\
\text { weight }(g)\end{array}$ & $\begin{array}{l}\text { Saturated vapor } \\
\text { pressure }(\mathbf{k P a})\end{array}$ & $\begin{array}{l}\text { Mesopore volume }\left(V_{m}\right) \\
\left(\mathrm{cm}^{3}(\mathrm{STP}) \mathrm{g}^{-1}\right)\end{array}$ & $\begin{array}{c}\mathrm{C} \\
(\text { Constant })\end{array}$ & $\begin{array}{c}\text { Mean pore } \\
\text { diameter }(\mathbf{n m})\end{array}$ & $\begin{array}{c}\text { Sample area } \\
\left(\begin{array}{c}\text { a s, BET }) \\
\left(\mathbf{m}^{2} \mathbf{g}^{-1}\right)\end{array}\right. \\
\end{array}$ & $\begin{array}{c}\text { Total pore volume } \\
\left(\mathrm{p} / \mathbf{p}_{0}=0.982\right) \\
\left(\mathrm{cm}^{3} \mathrm{~g}^{-1}\right) \\
\end{array}$ \\
\hline VBE & 0.1520 & 91.009 & 19.148 & 117.43 & 9.1939 & $8.3343 \mathrm{E}+01$ & 0.1916 \\
\hline AVBE & 0.2101 & 88.515 & 23.163 & 107.57 & 8.8951 & $1.0082 \mathrm{E}+02$ & 0.2242 \\
\hline ASBE & 0.1127 & 88.541 & 23.063 & 114.42 & 9.1055 & $1.0038 \mathrm{E}+02$ & 0.2285 \\
\hline
\end{tabular}

Table 3 shows that mesopores volumes $\left(\mathrm{V}_{\mathrm{m}}\right)$ and sample areas $\left(\mathrm{a}_{\mathrm{s}}\right)$ of ASBE and AVBE are greater than those of VBE. BET analyses indicate changes in porous texture of the activated samples compared to the virgin bleaching clay. These results are due to performance of $\mathrm{HCl}$; dissolution of impurities, substitution of $\mathrm{H}+$ ions with other cations, release of $\mathrm{Al}+3$ cations, and increased number of mesopores and specific surface area [33].

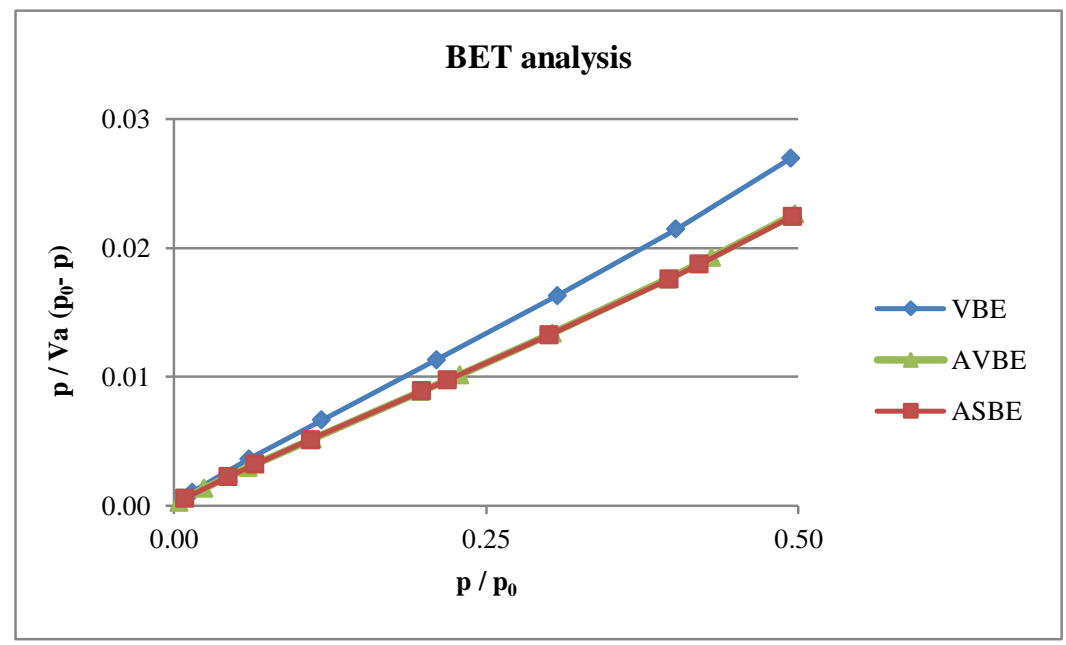

Figure 7. BET analysis of VBE, AVBE and ASBE samples

According to Figure 7, results obtained from BET test of AVBE and ASBE samples have a similar trend that is different from VBE sample. Having the samples in a relative pressure range of $0.0<\mathrm{P} / \mathrm{P}_{0}<0.5$, the value of constant $\mathrm{C}$ (affinity of the solid with the adsorbate and to the heat of adsorption) in ASBE was higher than AVBE. This means an adsorption improvement of nitrogen gas by ASBE in comparison with AVBE [34]. Furthermore, both ASBE and AVBE samples have almost an equal surface area of $100 \mathrm{~m}^{2} \mathrm{~g}^{-1}$, which are higher than VBE surface area $\left(\approx 83 \mathrm{~m}^{2} \mathrm{~g}^{-1}\right)$.

\subsubsection{BJH Analysis}

Samples characteristics and obtained parameters from BJH analysis are depicted in Figure 8 and Table 4.

Table 4. Results summary of BJH analysis

\begin{tabular}{cccccc}
\hline Sample & $\begin{array}{c}\text { Sample weight } \\
(\mathbf{g})\end{array}$ & $\begin{array}{c}\text { Saturated vapor pressure } \\
(\mathbf{k P a})\end{array}$ & $\begin{array}{c}\text { Pore volume }(\mathbf{V p}) \\
\left(\mathbf{c m}^{\mathbf{3}} \mathbf{g}^{-\mathbf{1}}\right)\end{array}$ & $\begin{array}{c}\text { Pore area }(\mathbf{a p}) \\
\left(\mathbf{m}^{\mathbf{2}} \mathbf{g}^{-\mathbf{}}\right)\end{array}$ & $\begin{array}{c}\text { Pore radious }(\mathbf{r p}) \\
(\mathbf{n m})\end{array}$ \\
\hline $\mathbf{V B E}$ & 0.1520 & 91.009 & 0.1915 & 94.261 & 2.10 \\
$\mathbf{A V B E}$ & 0.2101 & 88.515 & 0.2231 & 111.08 & 2.10 \\
$\mathbf{A S B E}$ & 0.1127 & 88.541 & 0.2240 & 113.16 & 2.10 \\
\hline
\end{tabular}

According to Table 4, major peak occurs at $2.10 \mathrm{~nm}$. The pore radius size $\left(\mathrm{r}_{\mathrm{p}}\right)$ in three samples represents the family of mesopores [35]. Even though pores radius are similar in 3 samples, but pores volumes $\left(\mathrm{V}_{\mathrm{p}}\right)$ and pores area $\left(\mathrm{a}_{\mathrm{p}}\right)$ in AVBE and ASBE are more than VBE sample. On this basis, clay regeneration and activation raise pores volume and 
surface and consequently enhancement provides higher adsorption capacity for ASBE in comparison with VBE [36].

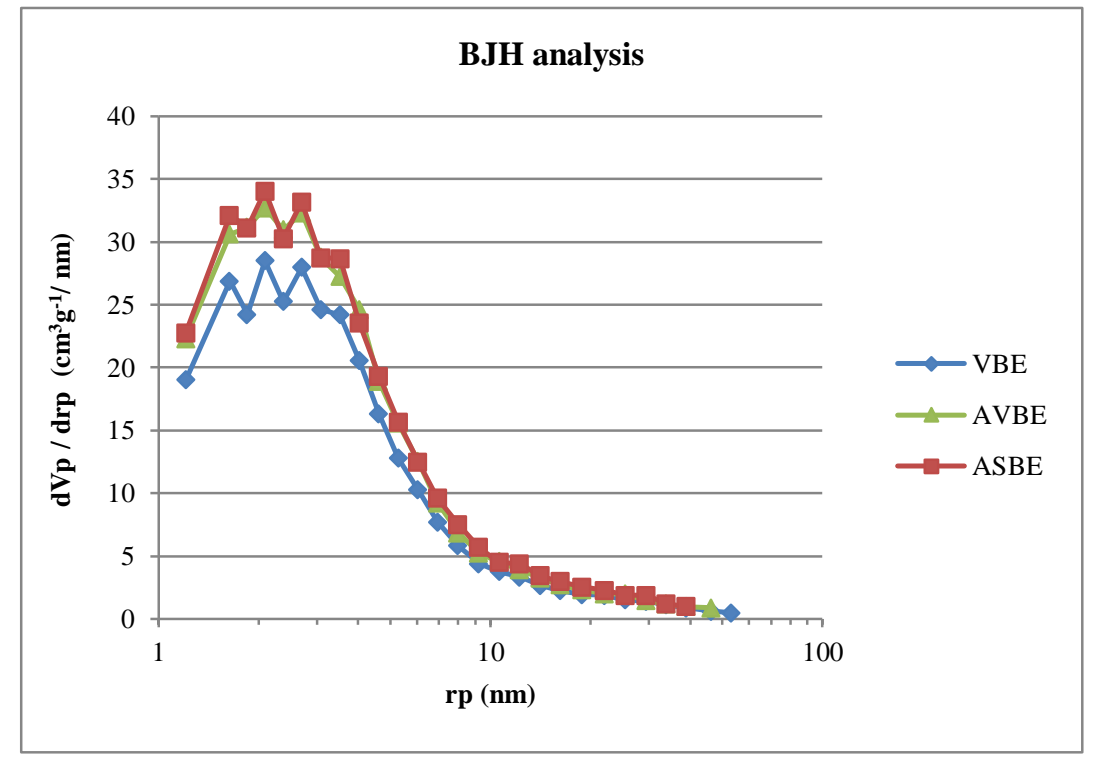

Figure 8. Pore distribution of VBE, AVBE and ASBE sample in BJH analysis

Figure 8 depicts the pores distribution curves as a heterogeneous distribution of slits with a major peak. As shown in this figure, there is a maximum radius in each sample (VBE, AVBE and ASBE). It is necessary to mentioned that the value of $\frac{d v_{p}}{d r_{p}}$ are almost the same.

\subsubsection{XRD Patterns}

Figure 8 shows results of XRD test on the samples. Samples including VBE, SBE, AVBE, and ASBE have different patterns but with similar chemical components in some extent.

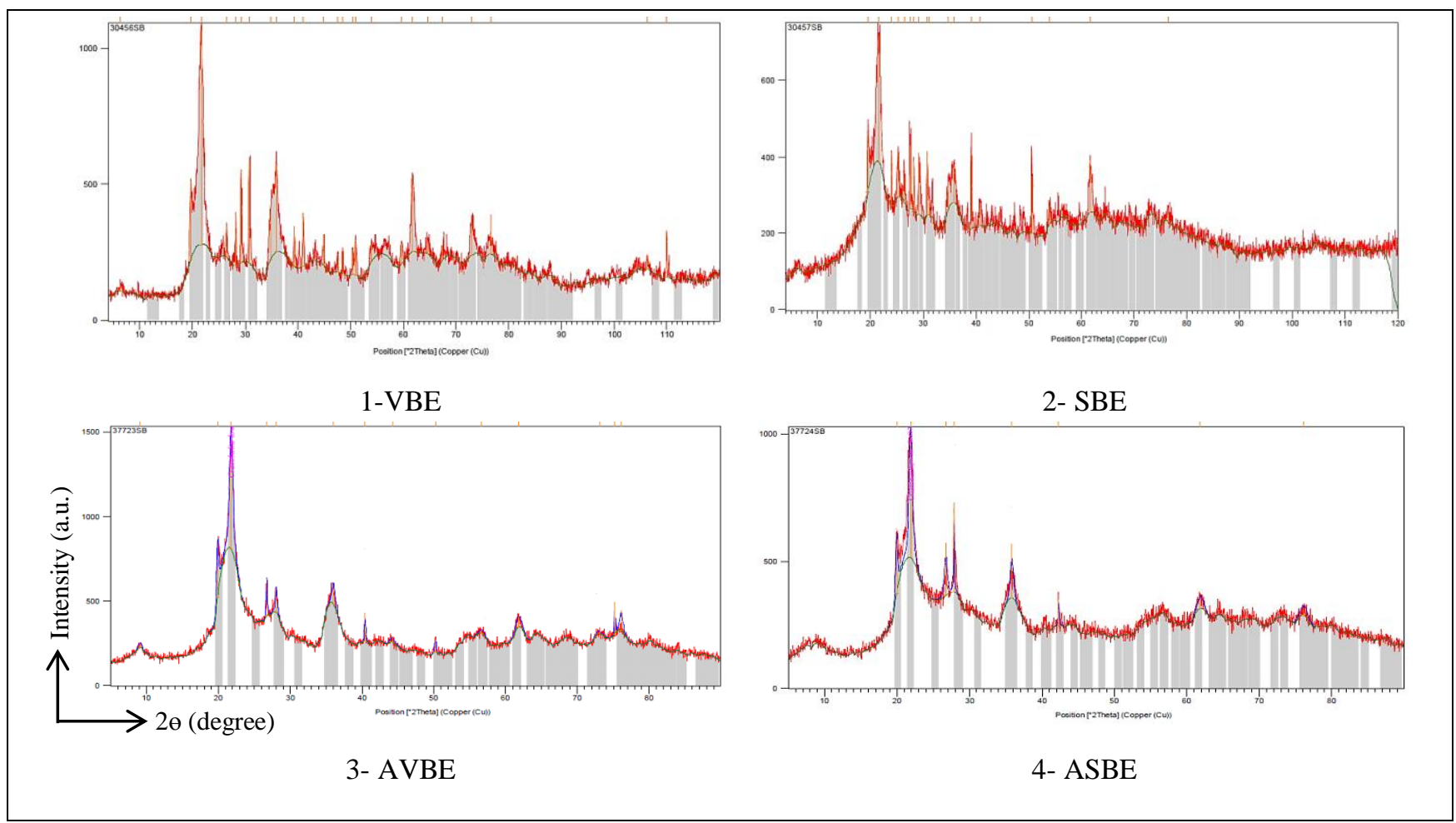

Figure 9. X-ray diffraction of (1) VBE, (2) SBE, (3) AVBE, and (4) ASBE samples

The figure shows the same diffraction peaks for them. A characteristic of montmorillonite (M), the presence of quartz (Q) and silicon nitride (S) are detected for all of the clay samples. The sample peaks occurred at 20, 21.5, 29, 35, 62 degree of $2 \theta$. The results show that physicochemical treatment does not affect the principal structure of montmorillonite 
clay [37]. The clay structure shrinks and expands by temperature variations [20].

\subsubsection{FTIR Spectra}

Figure 10 demonstrates results of FTIR spectra for the 4 samples including SBE, VBE, AVBE, and ASBE.

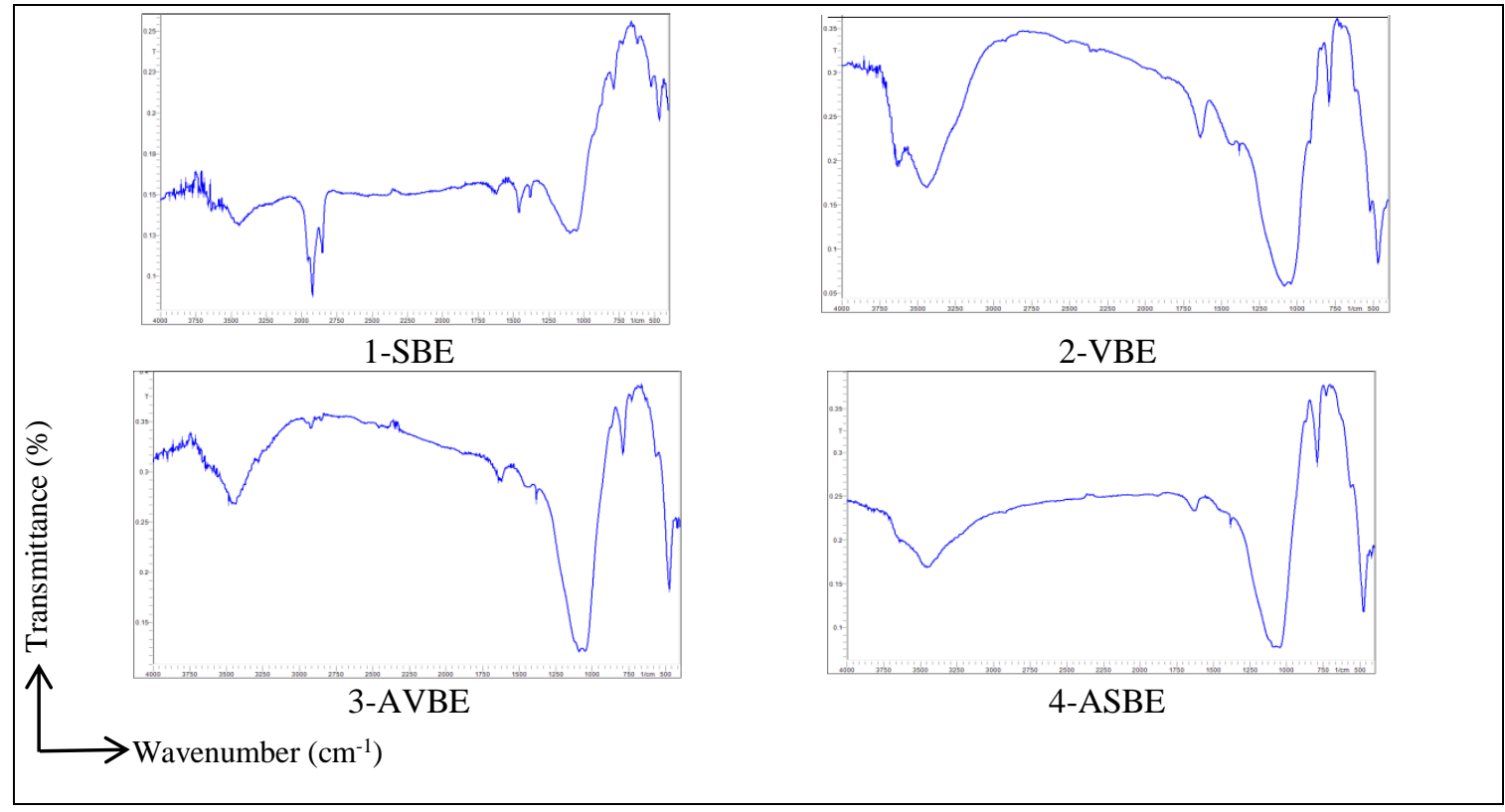

Figure 10. FTIR spectra of (1) SBE, (2) VBE, (3) AVBE, and (4) ASBE samples

FTIR spectra in Figure 10 confirms presence of montmorillonite structure in the materials in particular the band near $3460-3650 \mathrm{~cm}^{-1}$ attributed to the stretching vibrations of the interlayer water molecule. The band occurs at $1650 \mathrm{~cm}^{-1}$ (O-H vibration), $1050 \mathrm{~cm}^{-1}$ (Si-O stretching), $792 \mathrm{~cm}^{-1}$ (Si-O vibration of quartz impurities), and below $520 \mathrm{~cm}^{-1}$ (Si-OAl bending). Having identical spectra for VBE, AVBE, and ASBE, it indicates that thermal remediation followed by acid washing does not modify bleaching earth montmorillonite structure [38]. SBE sample exhibits the characteristics of organic residual oil bands. This means that a large shoulder between 1042 and $1084 \mathrm{~cm}^{-1}$ is attributable to carboxylic acids (C-O), $1458 \mathrm{~cm}^{-1}, 2918 \mathrm{~cm}^{-1}$ and $3458 \mathrm{~cm}^{-1}$ correspond to alkane, $\mathrm{C}-\mathrm{H}$ with alkane vibration and $\mathrm{O}-\mathrm{H}$, respectively. These bands in SBE disappear after thermal remediation. In fact, entire organic adsorbed residues in the pores are eliminated by thermal remediation and acid washing [39].

\subsubsection{SEM Test}

In Figure 11, SEM micrographs of VBE and SBE show a similar morphology, while those of ASBE and AVBE show a flattened texture because of thermal treatment and acid washing activation. In addition, just ASBE and AVBE show considerable enhancement and they have enhanced pore volumes and surface areas, whereas the others (SBE and VBE) serve as controller in experiments. 


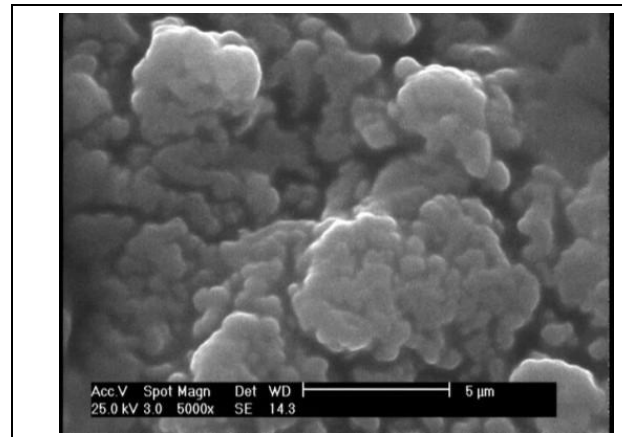

(a)

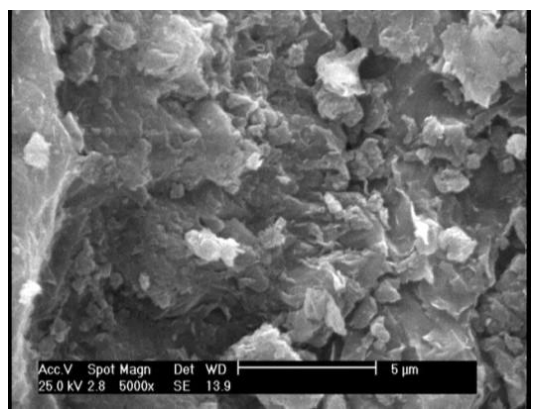

(c)

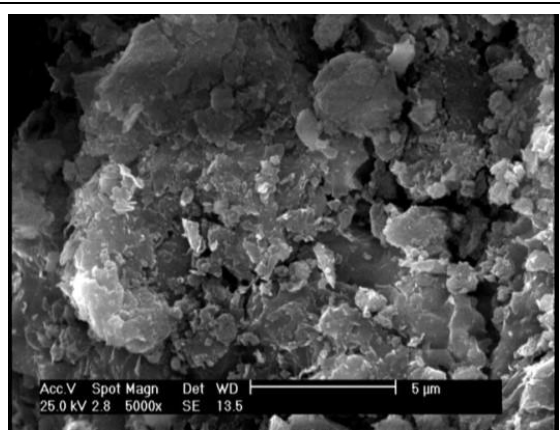

(b)

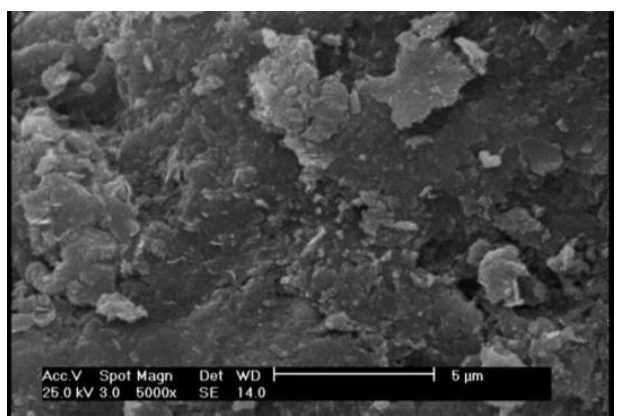

(d)

Figure 11. SEM observations of (a) SBE; (b) VBE; (c) AVBE; and (d) ASBE samples

The optimum sample (ASBE) shows that thermal remediation and acid washing activation improves surface area, pore volume, and surface morphology, while keep some physico-chemical characteristics constant. These properties cause a higher tendency towards adsorption of impurities (Figure 6) and color enhancement (Figure 5) compared to the other 3 samples, SBE, VBE, and AVBE.

\section{Conclusion}

Treating SBE (consumed in used-motor oil purification plant), conducting thermal remediation followed by acid washing activation at $650{ }^{\circ} \mathrm{C}$ and $1 \mathrm{M} \mathrm{HCl}$ conclude an optimum sample with high adsorption capacity. Indeed, applying the treatment on SBE increases surface area and pores volume in ASBE, while the physicochemical clay structure is unchanged. Moreover, performance of ASBE is similar to AVBE and better than VBE in adsorption of impurities. Ensuing, recovery of SBE containing used motor oil prevents environmental pollution and save resources such as clay and motor oil.

\section{Acknowledgements}

The authors are grateful to K. N. Toosi University of Technology for providing research materials, equipment and fund for this research. In addition, the authors wish to thank Miss Hengameh Zatali (environmental laboratory specialist) for her assistance during the experiments.

\section{References}

[1] Shahi, M., Sabour, M.R., Amiri, A. and Ghasemnezhad, M., "Cleaning spent bleaching clay through using solvent extraction method and RSM statistical approach”. Cumhuriyet Science Journal, 36(7), (2015): pp.23-40. DOI: 10.17776/csj.66920.

[2] Hussin, F., Aroua, M.K. and Daud, W.M.A.W., "Textural characteristics, surface chemistry and activation of bleaching earth: A review”. Chemical Engineering Journal, 170(1), (2011): pp.90-106. DOI:10.1016/j.cej.2011.03.065.

[3] Didi, M.A., Makhoukhi, B., Azzouz, A. and Villemin, D., "Colza oil bleaching through optimized acid activation of bentonite: A comparative study”. Applied Clay Science, 42(3), (2009): pp.336-344. DOI: 10.1016/j.clay.2008.03.014.

[4] Sabah, E., Cinar, M. and Celik, M.S., "Decolorization of vegetable oils: adsorption mechanism of $\beta$-carotene on acid-activated sepiolite”. Food Chemistry, 100(4), (2007): pp.1661-1668. DOI:10.1016/j.foodchem.2005.12.052.

[5] Lee, C.G., Seng, C.E. and Liew, K.Y., "Solvent efficiency for oil extraction from spent bleaching clay". Journal of the American Oil Chemists' Society, 77(11), (2000): pp.1219-1223. DOI: 10.1007/s11746-000-0190-6.

[6] Pollard, S.J., Sollars, C.J. and Perry, R., "The reuse of spent bleaching earth: a feasibility study in waste minimization for the edible oil industry”. Bioresource Technology, 45(1), (1993): pp.53-58. DOI: 10.1016/0960-8524(93)90143-y.

[7] Mohammadnejad, M., Ghazvini, M., Mahlia, T.M.I. and Andriyana, A., "A review on energy scenario and sustainable energy in Iran”. Renewable and Sustainable Energy Reviews, 15(9), (2011): pp.4652-4658. DOI: 10.1016/j.rser.2011.07.087. 
[8] Botas, J. A., Moreno, J., Espada, J. J., Serrano, D. P., and Dufour, J., "Recycling of used lubricating oil: Evaluation of environmental and energy performance by LCA". Resources, Conservation and Recycling, 125, (2017): 315-323. DOI: 10.1016/j.resconrec.2017.07.010.

[9] Awaja, F. and Pavel, D., "Design Aspects of Used Lubricating Oil Re-Refining”. Elsevier, Netherlands, (2006). DOI: 10.1016/b978-044452228-3/50001-7.

[10] Yang, Y., Fu, T., Bao, W., and Xie, G. H., "Life cycle analysis of greenhouse gas and PM 2.5 emissions from restaurant waste oil used for biodiesel production in China". Bio-Energy Research, 10(1), (2017): pp. 199-207. DOI: 10.1007/s12155-016-9792-5.

[11] Shahi, M., Sabour, M.R. and Dezvareh, G.A., "Reactive dye extraction utilizing regenerated bleaching earth". Global Journal of Environmental Science and Management, 3(3), (2017): pp.299-310. DOI: 10.22034/gjesm.2017.03.03.007.

[12] Nursulihatimarsyila, A. W. ,Cheah, K.Y., Chuah, T.G., Siew, W.L. and Choong, T. S.Y. , "Deoiling and regeneration efficiencies of spent bleaching clay". American Journal of Applied Sciences, 7(3), (2010): pp.434-437. DOI: 10.3844/ajassp.2010.434.437.

[13] Adams, J.M., "Synthetic organic chemistry using pillared, cation-exchanged and acid-treated montmorillonite catalysts - a review". Applied Clay Science, 2(4), (1987): pp.309-342. DOI: 10.1002/chin.198812379.

[14] Yildiz N., Aktas Z. and Calimi A., "Sulphuric acid activation of a calcium bentonite". Particulate Science and Technology. 22(1), (2004): pp.21-33. DOI: 10.1080/02726350490422392.

[15] Meesuk, L. and Vorasith, N., "The use of bentonite to remove dark colour in repeatingly used palm oil". Journal of Environmental Science and Health Part A, 41(6), (2006): pp.1189-1200. DOI: 10.1080/10934520600623083.

[16] Noyan, H., Önal, M. and Sarıkaya, Y., "The effect of sulphuric acid activation on the crystallinity, surface area, porosity, surface acidity, and bleaching power of a bentonite". Food Chemistry, 105(1), (2007): pp.156-163. DOI: 10.1016/j.foodchem.2007.03.060.

[17] Sarioğlan, Ş., Yüzer, H. and Koral, M., "Acid activation and bleaching performance of Turkish (somas) bentonite in crude soybean oil”. Particulate Science and Technology, 28(4), (2010): pp.298-308. DOI: 10.1080/02726351.2010.496296.

[18] Mana, M., Ouali, M.S., De Menorval, L.C., Zajac, J.J. and Charnay, C., "Regeneration of spent bleaching earth by treatment with cethyltrimethylammonium bromide for application in elimination of acid dye". Chemical Engineering Journal, 174(1), (2011): pp.275-280. DOI: 10.1016/j.cej.2011.09.026.

[19] Emam, E. A. and Shoaib; A. M., "Re-refining of used lube oil, I- by solvent extraction and vacuum distillation followed by hydrotreating”. Journal Petroleum \& Coal ,55 (3), (2013): pp. 179-187. DOI:10.21608/ejchem.2015.1010.

[20] Meziti, C. and Boukerroui, A., "Regeneration of a solid waste from an edible oil refinery". Ceramics International, 37(6), (2011): pp.1953-1957. DOI: 10.1016/j.ceramint.2011.02.016.

[21] Loh, S. K., Cheong, K. Y., and Salimon, J., "Surface-active physicochemical characteristics of spent bleaching earth on soilplant interaction and water-nutrient uptake: A review". Applied Clay Science, 140, (2017): pp.59-65. DOI: 10.1016/j.clay.2017.01.024.

[22] Al-zahrani, A. A. and Alhamed, Y. A., "Oil removal from spent bleaching earth by solvent extraction”. Journal of Environmental and Health, 35(9), (2000): pp.1577-1590. DOI: 10.1080/10934520009377056.

[23] Boukerroui, A., Belhocine, L., and Ferroudj, S., "Regeneration and reuse waste from an edible oil refinery". Environmental Science and Pollution Research, (2017): pp.1-8. DOI: 10.1007/s11356-017-9971-8.

[24] Komadel, P. and Madejová, J., “Acid activation of clay minerals”. Handbook of Clay Science, (2013): pp.385-408. DOI: 10.1016/b978-0-08-098258-8.00013-4.

[25] Tan, Y.A., Kuntom, A., Lee, C.K. and Low, K.S., "Comparative evaluation of palm oil color measurement using a prototype palm oil colorimeter". Journal of the American Oil Chemists' Society, 81(8), (2004): pp.733-736. DOI: 10.1007/s11746-004-0970-z.

[26] Xin, X., Si, W., Yao, Z., Feng, R., Du, B., Yan, L. and Wei, Q., “Adsorption of benzoic acid from aqueous solution by three kinds of modified bentonites". Journal of Colloid and Interface Science, 359(2), (2011): pp.499-504. DOI: 10.1016/j.jcis.2011.04.044.

[27] Tabak, A., Yilmaz, N., Eren, E., Caglar, B., Afsin, B. and Sarihan, A., "Structural analysis of naproxen-intercalated bentonite (Unye)". Chemical Engineering Journal, 174(1), (2011): pp.281-288. DOI: 10.1016/j.cej.2011.09.027.

[28] Lee, C., Lee, K., Choi, H. and Choi, H.P., "Characteristics of thermally-enhanced bentonite grouts for geothermal heat exchanger in South Korea”. Science in China Series E: Technological Sciences, 53(1), (2010): pp.123-128. DOI: 10.1007/s11431-009-0413-9.

[29] Huang, H., Yi, D., Lu, Y., Wu, X., Bai, Y., Meng, X. and Shi, L., "Study on the adsorption behaviour and mechanism of dimethyl sulfide on silver modified bentonite by in situ FTIR and temperature-programmed desorption". Chemical Engineering Journal, 225, (2013): pp.447-455. DOI: 10.1016/j.cej.2013.04.018.

[30] Wang, Q., Cui, Y.J., Tang, A.M., Barnichon, J.D., Saba, S. and Ye, W.M., "Hydraulic conductivity and microstructure changes of compacted bentonite/sand mixture during hydration". Engineering Geology, 164, (2013): pp.67-76. DOI: 10.1016/j.enggeo.2013.06.013.

[31] Önal, M., "Swelling and cation exchange capacity relationship for the samples obtained from a bentonite by acid activations and heat treatments". Applied Clay Science, 37(1), (2007): pp.74-80. DOI: 10.1016/j.clay.2006.12.004.

[32] Meziti, C. and Boukerroui, A., "Regeneration of a solid waste from an edible oil refinery". Ceramics International, 37(6), (2011): pp.1953-1957. DOI: 10.1016/j.ceramint.2011.02.016. 
[33] Zdravkov, B., Čermák, J., Šefara, M. and Janků, J., "Pore classification in the characterization of porous materials: A perspective". Open Chemistry, 5(2), (2007): pp.385-395. DOI: 10.2478/s11532-007-0039-3.

[34] Caglar, B., Afsin, B., Tabak, A. and Eren, E., "Characterization of the cation-exchanged bentonite by XRPD, ATR, DTA/TG analyses and BET measurement". Chemical Engineering Journal, 149(1), (2009): pp.242-248. DOI: 10.1016/j.cej.2008.10.028.

[35] Leofanti, G., Padovan, M., Tozzola, G. and Venturelli, B., "Surface area and pore texture of catalysts". Catalysis Today, 41(1), (1998): pp.207-219. DOI: 10.1016/s0920-5861(98)00050-9.

[36] Hayati Ashtiani, M., "Characterization of nano porous bentonite (montmorillonite) particles using FTIR ,BET and BJH analyses”. Particle \& Particle Systems Characterization, 28(34), (2011): pp.71-76. DOI: 10.1002/ppsc.201100030.

[37] Carlson, L., Karnland, O., Oversby, V.M., Rance, A.P., Smart, N.R., Snellman, M., Vähänen, M. and Werme, L.O., "Experimental studies of the interactions between anaerobically corroding iron and bentonite". Physics and Chemistry of the Earth, Parts A/B/C, 32(1), (2007):pp.334-345. DOI: 10.1016/j.pce.2005.12.009.

[38] Invernizzi, C., Daveri, A., Vagnini, M., and Malagodi, M., "Non-invasive identification of organic materials in historical stringed musical instruments by reflection infrared spectroscopy: a methodological approach". Analytical and bioanalytical chemistry, 409(13), (2017): pp. 3281-3288. DOI: 10.1007/s00216-017-0296-8.

[39] Tsai, W.T., Chen, H.P., Hsieh, M.F., Sun, H.F. and Chien, S.F., "Regeneration of spent bleaching earth by pyrolysis in a rotary furnace". Journal of Analytical and Applied Pyrolysis, 63(1), (2002):pp.157-170. DOI: 10.1016/s0165-2370(01)00150-4. 